\title{
Teachers' Achievement Goals: A Mixed Method
}

\author{
Zeynep Demirtaş ${ }^{1}$, Nihan Arslan ${ }^{2, *}$ \\ ${ }^{1}$ Faculty of Education, Sakarya University, Turkey \\ ${ }^{2}$ Faculty of Education, FSM Vakıf University, Turkey
}

Copyright $\bigcirc 2018$ by authors, all rights reserved. Authors agree that this article remains permanently open access under the terms of the Creative Commons Attribution License 4.0 International License

\begin{abstract}
In this study, the first aim of the research is to adjust the scale of teachers' achievement goals to the Turkish culture. The second aim of the research is to get point of view about their achievement goals within the qualitative questions prepared by base on scale items. The mixed method has been used in the survey. The qualitative and quantitative data has been obtained in accordance with the aims of the research. In the first step of the survey, it has been worked on scale adaptation. In the second step, the questions of interview have been prepared by basing on scale items of the qualitative survey and asked to the teachers. In accordance with scale adaptation study, The Scale of Teachers' Achievement Goals, developed by Papaioannou and Christodoulidis in 2007, has been translated to Turkish. The Turkish form of the scale has been carried out on 235 teachers and examined via the reliability analysis and confirmatory factor analysis. The reliability co-efficient of the scale has been found as .73. The interview method has been used for the qualitative data in the research. In accordance with views of experts, it has been put into a final form to the interview form. Determined by maximum variation sampling, one of aimed sampling methods, 25 teachers who work in different socio-economic schools status and subjects with different demographic variables have made a working group. The data acquired in the wake of face-to-face meetings has been analyzed by using content analysis. According to views of teachers, it has been stated that student behaviors, the culture of the school, professional properties, personal and environmental factors encourage teachers to success.
\end{abstract}

Keywords Teachers' Achievement Goals, Success, Teacher

\section{Introduction}

There are many interrelated and complex factors affecting people's life. Some of them are biological, psychological, sociological and cultural factors. Each factor has countless concepts in itself. Human development goes on as a process together with biological, cognitive and socio emotional structures and human development consists of phases. As a social being, human cannot be separated from these interrelated factors which interact with each other. People's motivation is also closely related to their perception of self-efficacy. Bandura's self-efficacy term is based on his Social Learning Theory [13]. In the theory, self-efficacy is the capacity of handling different situations, organizing necessary activities to show a particular performance, an individual's perception, faith and judgement of his capacity to succeed [18]. According to Bandura, self-efficacy has four subdivisions: mastery experiences, vicarious experiences, social persuasion and physical and emotional reactions [8]. In Maslow's hierarchy of needs theory, when belongingness and love needs are completely satisfied, people show higher level of motivation and thus, their achievement goals are promoted [9]. Apart from Maslow's theory, McClelland [27] identifies human needs as the need of achievement, loyalty and power. Achievement motivation is the most important need in this context [5]. Self-determination theory describes achievement as a psychological need for an individual [29]. People's comprehension and perception of the world and perception of self, their references play a crucial role in conceptualization of their thoughts. While achievement motivation is seen as both the individual differences and the characteristics that individual has, it is stated that people with motivation have the potential of working in determination and coping with difficulties in order to reach their personal and professional goals [23]. Achievement motivation puts forward perfection, winning, the feeling of inner achievement, and the need for achievement [27]. In other word, people try to do their best with desire to achieve and achievement motivation. The desire to achieve evolves in the context of the relation between state variables and internal sense of accomplishment [5].

The theory of achievement goals is based on the aims of students' learning tasks while examining their behavior towards learning. Therefore, this theory is based on the way individuals think about themselves and their duties 
rather than being motivated or not. The overall approach to achievement goals includes cognitive, sensory processes that students use to evaluate their beliefs and performances in order to achieve success [2]. There are many studies about achievement in literature and another remarkable concept related to achievement goals. Achievement goals theory produced and studied by Dweck and Leggett [16], examines the degree of individuals' motivation related to the goals they set. Achievement goals orientation is not only a motivational approach related to individual's learning but also related to his attitude and approaches internalized while heading towards doing anything. According to achievement goal theory, Pintrich and Schunk stated that people who have learning goal, are interested in contents such as increasing their ability, giving priority to learning, trying to comprehend themes better and they have the characteristics such as requesting feedback from others about their performance, trying to outperform others and to appear successful [6].

Achievement goals orientation was initially divided into two; learning orientation which aims improve competence and performance orientation described as proving competence and avoiding being appeared incompetent $[7,16]$. After the increase in the number of related studies, the extension and content of achievement goal orientation was clarified and finally achievement goals theory was developed [29]. Various definitions related to the achievement goal orientation were used previously, but the mostly used structure today is the triple achievement goal model; mastery, performance-approach and performance avoidance. Elliot and Harackiewicz define the achievement goal orientation as a model consisted of triple structure. From this point of view, according to achievement goal orientation, mastery goals: individuals acquire basic skills by learning the present subject / content, performance-approach: main objective in this approach is to show accomplishment and competence in learning the content and material and to improve the level of competence, performance-avoidance: this goal includes the situations like avoiding tasks and delaying responsibilities with the least effort [30].

Achievement goals orientation is a source which motivates people to reach achievement and it is related to the way people choose while trying to achieve their goals [10]. In other words, goal orientation explains why and how individuals try to achieve their goals rather than the goals identifies the aims of goal orientation in broader perspective and finally, is interested in the orientations revealing the attitudes which play important role in expressing the situations containing individual's experiences [22]. Oral and Özgüngör [28] states that achievement goal orientations of people differ from others and some people give importance to learning goals, while others try to prove their skills persistently and to avoid situations in which they appear incompetent. It can be said that individuals develop their personal success tendencies due to the reasons rooted by many internal and external factors in their private and professional lives. Being under pressure two times more than other jobs about being a model and doing the best for their work, teachers need to do their best to meet the requirements expected from them.

Achievement goals include how individuals define the concept of success in educational environments. Teachers work to achieve their achievement goals in the classroom [12]. Teachers' achievement goals can be a performance-approach goal (to show superior teaching skills to others) or a performance-avoidance goal (to mask lower teaching ability) or mastery goals (to improve teaching competence). These various achievement goals are to train teachers promotes learning outcomes in different classes. Achievement goals-focused teachers conceptualize competent teachings that encourage the growth and mastery of the student [41]. Teachers' achievement goals for teaching are defined as different orientations towards teaching competence, such as displaying the process of improving teaching competence. Teachers differ in the extent to which they support different types of achievement goals [7]. Akın, Çetin and Gündüz [3] examined the relationship between motivation and job satisfaction with success orientations. It was found that learning-approach success orientation was related positively to motivation and job satisfaction while learning-avoidance, performance-approach and performance-avoidance success directions were related negatively to motivation and job satisfaction. It has been determined that teachers with higher learning achievement have a positive perception in terms of professional development. It is stated that teachers with high performance avoidance tendency have a negative perception in terms of their personal and professional development. These results show that teachers achievement goals has an important and strong influence on their personal and professional competencies [6]. In this regard, it has been aimed to not only adaptation the scale of Teachers' Achievement Goals to Turkish culture to determine the success tendencies of the teachers in the quantitative study, but also determine if they face feeling of inadequate, what the factors prompting them to be successful are, what they do to be more successful for their jobs and which distinctive features differing from their colleagues they have in the qualitative study. The first research question of the study is the scale a valid and reliable for Turkish culture? The second research question is to examine teachers' point of view of achievement goals.

\section{Method}

The mixed method has been used in this research. According to this method, qualitative and quantitative data has been acquired for the purposes of the research. It is seen that the mixed method is defined by similar forms in 
the related literature. In accordance with these definitions, if it is necessary to make a common definition, mixed method has been defined as a search model where qualitative and quantitative data has been acquired and analyzed at the same time or consecutively in single or multi staged surveys. Sequential explanatory design was used in the research. In the research, firstly quantitative data were collected to explain qualitative data.

\subsection{Participants}

The study of the scale has been carried out on 235 teachers. In the scope of the search the sampling consists of 139 female and 96 (39\%) male teachers. The age average of the sampling is 32.9. Teachers' working seniority averages is $10.5(\mathrm{SD}=7.9)$. The teachers who make the sample of the research are working in Istanbul and Sakarya. Qualitative sampling of the research consisting of 25 teachers, the group has 21 female and 4 male teachers; 23 teachers who have bachelor's degree and 2 teachers who have post graduate degree. Average age of the group is 27.2 and average seniority is about 4.8 years.

\subsection{Instruments}

\section{Teachers' Achievement Goals}

The rating of the scale of Teachers' Achievement Goals consisting of 12 items and 3 subscales has been done via
Five Point Likert Scale [31] The reliability co-efficient of the scale has been calculated as .73. In the scope of study for scale adjusting, the English form of the scale has been translated into Turkish by researchers and the point of views of the experts has been received about it. In the scope of the survey, confirmatory factor analysis, recovered total item correlation and reliability have been examined.

\section{Findings}

\section{Study 1}

\section{Item Analysis and Reliability}

As a result of the analysis carried out to determine the item discrimination of the scale, it has been found that recovered correlation coefficient varies from .11 to .57 . Cronbach's alfa coefficient has been found as .73 for the whole scale.

\section{Construct Validity}

The fit index obtained as a result of confirmatory factor analysis of the scale $\left(\mathrm{x}^{2}=146.78, \mathrm{sd}=51, \mathrm{p}=0.0000\right.$, $\mathrm{RMSEA}=.08, \mathrm{NFI}=.89 \mathrm{NNFI}=.90, \mathrm{CFI}=.92, \quad \mathrm{IFI}=.92$, $\mathrm{RFI}=.86$, and $\mathrm{SRMR}=.06$ ) shows that three dimensional model fits. The standardized regression weights belonging to confirmatory factor analysis has been given on Figure 1 .

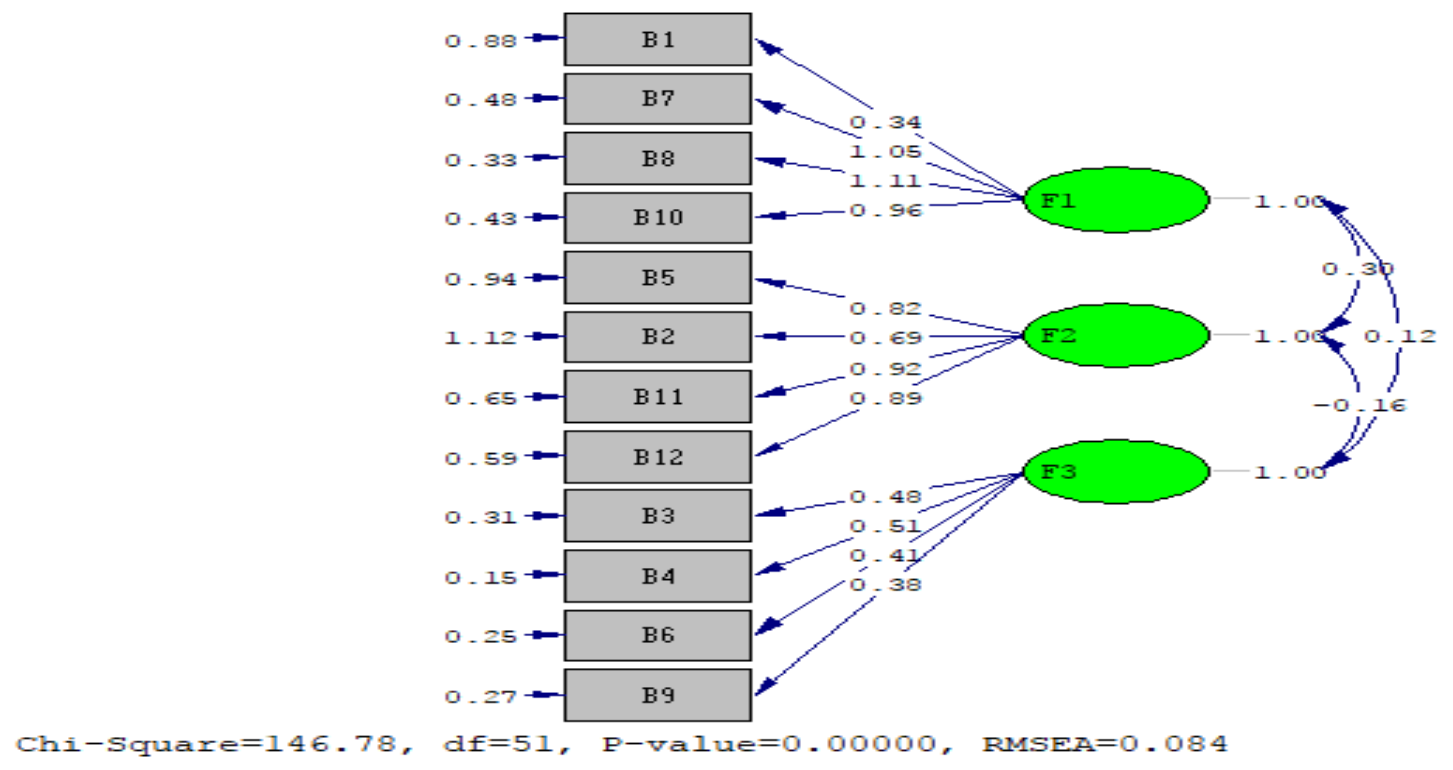

Figure 1. Confirmatory factor analysis results 


\section{Study 2}

\section{Data Collection}

The data has been acquired via an interview form prepared by searchers and structured by an expert opinion $(n=4)$. The interview form consists of four open ended question about determining their views related to teachers' achievement goals, their success factors, the things they do to be successful and their different characteristics making them more successful than their colleagues. Making a work schedule related to periods of time when teachers are free, researchers have had a face to face interview. In each interview lasting about 20 minutes, data has been recorded by taking notes on teachers' request without sound recording. Teachers have been also asked some follow up or alternative questions to provide them to express themselves better. Being written during the interview, views have been presented to the teachers and teachers have been asked to confirm them at the end of the interview.

\section{Data Analysis}

The data acquired as a result of interviews has been examined via content analysis. The content analysis includes categorizing similar data in common topics and making necessary arrangements and comments to present it to the readers in a suitable way [44]. In the survey, data has been coded by two of the researchers being independent of each other for the content analysis. The data coded after independent coding period has been gathered and common coding has been taken in the same way and data for different coding has been examined together and common coding has been made with agreement. For the coding made in the second stage, topics representing coding have been determined together. Next to the codes, the teachers having those views have been written with the symbols such as T1, T2 ... T25. Percent and frequency value of the views the teachers express have also been added. The questions asked in qualitative research are listed below.

- What are your views about the description of the achievement goals in your job?

- What factors that encourage the achievement goals in your job?

- What are your practices to succeed in the achievement goals?
- What features that make you more successful about the achievement goals than your colleagues?

\section{Qualitative Findings}

The situations where teachers describe the achievement goals inadequacy in your job and their views about what they do to resolve this situation have been presented on Table 1.

According to Table 1, teachers' views about achievement goals inadequacy have been categorized in four topics. About inadequacy case, it has been stated 64 percent of teachers seldom feel inadequate, 24 percent of them sometimes feel inadequate and 12 percent of them never feel inadequate. As the reasons for inadequacy, 16 percent of teachers select unproductive lesson, 8 percent of them select subject deficiency, unwilling students, running out of patience, being inexperienced, 4 per cent of them select being unable to fall to the level of the student, being unable to answer questions of students and being bachelor of the faculty of science and letter. In case of inadequacy, it is stated that 24 percent of teachers feel willing to compensate inadequacy, 16 percent of them feel unproductive, 12 percent of them feel bad, desperate and unhappy, 8 percent of them is angry at themselves, panic or self-question about job and 4 per cent of them feel anxious, sad, unconfident and exhausted. To defeat inadequacy, it is stated that 56 of the teachers make research about the branch, 28 of them take an advise of an experienced colleague and improve themselves, 16 percent of them think about solutions by being alone, 12 percent of them use different teaching techniques for the lessons and concentrate on the things they do more successfully, 8 percent of them attend career development course or seminars, use different materials for the lessons and revise the lessons, 4 percent of them make good preparations for the lessons, do additive activities and form their own method. Some of teachers' views are quoted below.

- "I never feel inadequate. I love my job, negative things never discourage me. If I felt inadequate, I would do my best to destroy this feeling and find a solution."(T10)

- "Yes, I sometimes feel inadequate. In these conditions, I feel bad. To defeat this feeling, I take advices and information of my experienced colleagues and try to utilize them. I make research about the subject I feel inadequate on the net." (T12) 
Table 1. The views of teachers about achievement goals inadequacy

\begin{tabular}{|c|c|c|c|}
\hline Topic & Codes & f & $\%$ \\
\hline \multirow{3}{*}{ Inadequacy } & I seldom feel inadequate $(T 1, T 4, T 13, T 20, T 22, T 25)$ & 6 & 24 \\
\hline & $\begin{array}{c}\text { I sometimes feel inadequate }(T 2, T 5, T 6, T 7, T 8, T 9, T 11, T 12, T 14, T 15, T 16, T 17, T 18, T 21 \text {, } \\
T 23, T 24)\end{array}$ & 16 & 64 \\
\hline & I never feel inadequate $(T 3, T 10, T 19)$ & 3 & 12 \\
\hline \multirow{8}{*}{$\begin{array}{c}\text { Reasons } \\
\text { of Inadequacy }\end{array}$} & Unproductive lessons $(T 5, T 21, T 23, T 24)$ & 4 & 16 \\
\hline & Subject deficiency $(T 1, T 23)$ & 2 & 8 \\
\hline & Reluctant students $(T 4, T 20)$ & 2 & 8 \\
\hline & Running out of patience $(T 17, T 18)$ & 2 & 8 \\
\hline & Being inexperienced $(T 2, T 7)$ & 2 & 8 \\
\hline & Falling to the level of the student (T2) & 1 & 4 \\
\hline & Being unable to answer students' questions(T25) & 1 & 4 \\
\hline & Being bachelor of faculty of science and letters (T8) & 1 & 4 \\
\hline \multirow{12}{*}{$\begin{array}{l}\text { Feelings in case } \\
\text { of inadequacy }\end{array}$} & Being willing to compensate the case of inadequacy $(T 11, T 13, T 15, T 16, T 18, T 25)$ & 6 & 24 \\
\hline & Unproductive $(T 3, T 22, T 23, T 25)$ & 4 & 16 \\
\hline & $\operatorname{Bad}(T 3, T 7, T 12)$ & 3 & 12 \\
\hline & Desperate $(T 8, T 21, T 24)$ & 3 & 12 \\
\hline & Unhappy $(T 4, T 6, T 7)$ & 3 & 12 \\
\hline & Angry at himself/herself $(T 2, T 25)$ & 2 & 8 \\
\hline & Stressed/Panic $(T 14, T 22)$ & 2 & 8 \\
\hline & Self-questioning about job $(T 2, T 25)$ & 2 & 8 \\
\hline & Anxious (T4) & 1 & 4 \\
\hline & $\mathrm{Sad}(T 5)$ & 1 & 4 \\
\hline & Unconfident $T 16$ ) & 1 & 4 \\
\hline & Exhausted (T17) & 1 & 4 \\
\hline \multirow{12}{*}{$\begin{array}{l}\text { Things to do to } \\
\text { defeat inadequacy }\end{array}$} & $\begin{array}{c}\text { Making a research about the branch }(T 1, T 2, T 5, T 6, T 7, T 10, T 12, T 15, T 16, T 21, T 22, T 23, T 24 \text {, } \\
T 25)\end{array}$ & 14 & 56 \\
\hline & Taking an advice of an experienced colleague $(T 3, T 5, T 7, T 8, T 12, T 21, T 24)$ & 7 & 28 \\
\hline & Improving himself/herself $(T 9, T 11, T 13, T 18, T 21, T 24, T 25)$ & 7 & 28 \\
\hline & Thinking about a solution by being alone $(T 15, T 17, T 18, T 22)$ & 4 & 16 \\
\hline & Using different teaching techniques $(T 4, T 5, T 21)$ & 3 & 12 \\
\hline & Concentrating on the things they do successfully $(T 13, T 14, T 16)$ & 3 & 12 \\
\hline & Attending to career development course/workshops $(T 13, T 21)$ & 2 & 8 \\
\hline & Using different materials for the lesson(T2,T4) & 2 & 8 \\
\hline & Revising the subjects $(T 8, T 23)$ & 2 & 8 \\
\hline & Make good preparations for the lesson (T2) & 1 & 4 \\
\hline & Doing additive activities (T4) & 1 & 4 \\
\hline & Forming his/her own method(T21) & 1 & 4 \\
\hline
\end{tabular}

The teachers' views about the factors encouraging themselves to achievement goals for their job are presented on Table 2 . 
Table 2. Teachers views about the factors encouraging them to be achievement goals for their job

\begin{tabular}{|c|c|c|c|}
\hline Topic & Codes & f & $\%$ \\
\hline \multirow{4}{*}{ Student behaviours } & Willing students $(T 1, T 2, T 3, T 4, T 8, T 9, T 10, T 11, T 12, T 15, T 22, T 24, T 25)$ & 13 & 52 \\
\hline & Students' making progress $(T 1, T 7, T 10, T 13)$ & 4 & 16 \\
\hline & Students' being successful $(T 8, T 10)$ & 2 & 8 \\
\hline & Students' being active in the lesson(T4) & 1 & 4 \\
\hline \multirow{5}{*}{ School Culture } & Positive attitudes of my colleague $(T 3, T 11, T 15, T 19, T 20, T 22, T 24, T 25)$ & 8 & 32 \\
\hline & Peaceful job-working atmosphere $(T 6, T 11, T 17, T 19, T 21, T 22)$ & 6 & 24 \\
\hline & Positive attitude to the teachers from directors $(T 6, T 11, T 20, T 25)$ & 4 & 16 \\
\hline & Directors' working well $(T 18, T 25)$ & 2 & 8 \\
\hline & Directors' appreciating(T3) & 1 & 4 \\
\hline \multirow{3}{*}{ Professional features } & Salary $(T 11, T 13, T 14, T 16, T 17, T 18)$ & 6 & 24 \\
\hline & Holiday (T11) & 1 & 4 \\
\hline & Working hours $(T 11)$ & 1 & 4 \\
\hline \multirow{3}{*}{ Personal Factors } & Willing to be a good teacher $(T 4, T 5, T 7, T 8, T 23)$ & 5 & 20 \\
\hline & Willing to reach his/her goals $(T 2, T 12, T 23)$ & 3 & 12 \\
\hline & Willing to do best(T23) & 1 & 4 \\
\hline \multirow{4}{*}{ Environmental Factors } & An atmosphere where successful and ambitious colleagues exist $(T 5, T 16)$ & 2 & 8 \\
\hline & Appreciating efforts $(T 11, T 13)$ & 2 & 8 \\
\hline & Positive attitudes of parents $(T 11)$ & 1 & 4 \\
\hline & Appreciation of family (T24) & 1 & 4 \\
\hline
\end{tabular}

In Table 2, factors encouraging teachers to be achievement goals in their professional life have been categorized in five topics as school culture, professional features, environmental and personal factors. About student behaviors, teachers state that factors such as willing students(52 percent ), students' improving themselves(16 percent ),students' being successful ( 8 percent),students' being active in the lesson (4 percent) encourage them to be successful. In the scope of school culture, the cases of positive attitudes of colleagues (32 percent), peaceful job working area (24 percent)directors' positive attitudes to the teachers(16 per cent), directors 'doing well by working, directors' appreciating teachers (4 percent) encourage teachers to be successful. About professional features, salary ( 24 percent), holiday and working hours (4 percent) have an effect on being successful. Some teachers state that they are encouraged by environmental factors such as having successful/ambitious colleagues, appreciating their effort ( 8 percent), positive attitudes of parents and their family's appreciating them, while other teachers state that they are encouraged to be successful by personal factors as being willing to be a good teacher (20 percent) and reach their goals and do best. Some of teachers' views are quoted below.

- $\quad$ "The thing motivating and encouraging me to be successful is my students. If I see positive improvements on my students and I feel that I get a part in this case, I struggle to be more successful. Willingness and enthusiasm of my students becomes like a factor encouraging me to be successful. ”(T1)

- "Willing students, my colleagues and school administration are the factors encouraging me to be successful. These have to be existed to have a success encouragement. My colleagues'speaking well of me, being rewarded by my director encourages me my job more. The most important one is expectations of the students. As they are willing to learn, so you want to be successful."(T3)

Views about the things teachers do to achievement goals for their jobs are presented on Table 3.

When Table 3 has been examined, it is determined that 60 per cent of teachers follow the latest developments about the branch, 44 per cent of them attend educational seminars and courses, 36 of them take master's degree and read a lot, 16 per cent of them attend in service training and Exchange information with colleagues, 12 per cent of them watch educational videos and use different activities in the lessons, 8 per cent of them develop interesting lesson materials, attend self-help courses and follow technological developments, 4 per cent of them attend culture tours, get feedback from students, try to adapt the job and use technology in the lessons. Also a teacher states that he/she does nothing to be more successful. Some of teachers' views are quoted below.

- Inot only take master's degree but also attend seminars and exchange information with my colleagues to be more successful in my career and improve my professional career. I try to reflect the things I learn in my lessons and develop my lessons."(T13) 
- "I follow the latest developments about my branch by using various national and international sources. I am taking master's degree. I attend various in service training courses and seminars within the scope of The Ministry of Education. I also follow conferences and conversations about my branch."(T22)

- "I aim to be very successful in my job by following innovative approaches, technology and the latest developments about my branch."(T25)

Table 3. Views about the things teachers do to achievement goals for their jobs

\begin{tabular}{|c|c|c|c|}
\hline Topic & Codes & f & $\%$ \\
\hline \multirow{16}{*}{$\begin{array}{l}\text { The things } \\
\text { done }\end{array}$} & $\begin{array}{c}\text { Following the latest developments about the } \operatorname{branch}(T 3, T 4, T 6, T 7, T 8, T 9, T 10, T 11, T 15, T 16, T 19, T 21, T 22 \text {, } \\
\qquad 23, T 25)\end{array}$ & 15 & 60 \\
\hline & Attending courses and conferences about education $(T 6, T 7, T 8, T 11, T 13, T 15, T 16, T 20, T 21, T 22, T 23)$ & 11 & 44 \\
\hline & Taking master's degree $(T 2, T 9, T 10, T 11, T 12, T 13, T 21, T 22, T 23)$ & 9 & 36 \\
\hline & Reading books a lot $(T 2, T 3, T 7, T 9, T 10, T 19, T 20, T 21, T 22)$ & 9 & 36 \\
\hline & Attending in service training $(T 2, T 22, T 23, T 24)$ & 4 & 16 \\
\hline & Exchanging information with colleagues $(T 4, T 10, T 12, T 13)$ & 4 & 16 \\
\hline & Watching educational videos $(T 1, T 17, T 18)$ & 3 & 12 \\
\hline & Using different activities in the lesson $(T 3, T 9, T 16)$ & 3 & 12 \\
\hline & Developing interesting lesson materials $(T 3, T 4)$ & 2 & 8 \\
\hline & Attending self-help courses $(T 4, T 7)$ & 2 & 8 \\
\hline & Following technological developments $(T 23, T 25)$ & 2 & 8 \\
\hline & Joining culture tours $(T 10)$ & 1 & 4 \\
\hline & Getting feedbacks from students (T24) & 1 & 4 \\
\hline & Trying to adapt the job (T5) & 1 & 4 \\
\hline & Using technology in the lesson (T10) & 1 & 4 \\
\hline & I do nothing(T14) & 1 & 4 \\
\hline
\end{tabular}

Teachers' views about features providing them to be more successful than other colleagues are presented on Table 4 .

Table 4. Teachers' views about features providing them to be more successful than other colleagues

\begin{tabular}{|c|c|c|c|}
\hline Topic & Codes & $\mathbf{F}$ & $\%$ \\
\hline \multirow{3}{*}{ Appreciating students } & Caring students $(T 1, T 3, T 4, T 7, T 10, T 12, T 15, T 20, T 22, T 23)$ & 10 & 40 \\
\hline & Making a good contact with students $(T 1, T 2, T 3, T 4, T 10, T 11, T 15, T 22, T 23)$ & 9 & 36 \\
\hline & Tolerating students $(T 2, T 6, T 7, T 12, T 15)$ & 5 & 20 \\
\hline \multirow{15}{*}{ Characteristic features } & Being open to new ideas and learning $(T 4, T 10, T 11, T 21)$ & 4 & 16 \\
\hline & Being patient $(T 2, T 6, T 7, T 23)$ & 4 & 16 \\
\hline & Being determined $(T 5, T 9, T 14, T 25)$ & 4 & 16 \\
\hline & Emphatizing $(T 2, T 7, T 12)$ & 3 & 12 \\
\hline & Being tidy and disciplined $(T 5, T 9, T 20)$ & 3 & 12 \\
\hline & Being well-adjusted $(T 6, T 15, T 17)$ & 3 & 12 \\
\hline & Being perfectionist $(T 20, T 21)$ & 2 & 8 \\
\hline & Having sense of leadership $(T 16, T 25)$ & 2 & 8 \\
\hline & Being punctual $(T 14, T 19)$ & 2 & 8 \\
\hline & Being helpful $(T 7, T 22)$ & 2 & 8 \\
\hline & Being young and dynamic $(T 1, T 2)$ & 2 & 8 \\
\hline & Being a good listener $(T 7, T 22)$ & 2 & 8 \\
\hline & Setting clear goals $(T 9, T 25)$ & 2 & 8 \\
\hline & Being confident (T18) & 1 & 4 \\
\hline & Being honest(T16) & 1 & 4 \\
\hline \multirow{3}{*}{$\begin{array}{c}\text { The things done during } \\
\text { education }\end{array}$} & Using student-centered method $(T 8, T 10, T 11, T 22)$ & 4 & 16 \\
\hline & Using sense of humor in the lesson $(T 10, T 16)$ & 2 & 8 \\
\hline & Supporting lessons with materials (T13) & 1 & 4 \\
\hline \multirow{2}{*}{ Professional value } & Job love $(T 3, T 24, T 25)$ & 3 & 12 \\
\hline & Professional self - sacrifice $(T 3, T 13)$ & 2 & 8 \\
\hline
\end{tabular}


When examined on Table 4, teachers' views about features providing them to be more successful than other colleagues have been categorized in 4 topics as appreciating students, characteristic features, the things done during education and Professional value. In terms of appreciating students, 40 percent of teachers care students, 36 percent of them make a good contact with students and 20 percent of them understand the students. In terms of characteristic features, 16 per cent of the teachers say that they are open to the new ideas and learning and determined, 12 percent of them say that they are perfectionist, punctual, helpful, young, dynamic, a good listener and have a sense of leadership and set clear goals, 4 per cent of them say that they are confident and honest. In terms of the things done during education, it is stated that 16 per cent of the teachers use student-centered methods in their lessons, 8 percent of them use sense of humor in the lesson and 4 percent of them support lesson with materials. About Professional value, 12 percent of the teachers love their job and 8 percent of the make self-sacrifice for their jobs. Some of teachers' views are quoted below.

- "I am disciplined and tidy. My students are important for me, I spare time to explain them even the smallest thing. I am also perfectionist, I want the things I do be very good and I work for this." (T20)

- "I think I am more patient than my colleagues. I think that I make a good contact with my students because I am careful about my wording towards my students. I know my students are individual too and they deserve respect and I behave by thinking about this situation. I am trying to be a model for my students."(T23)

\section{Conclusions and Discussion}

In this study, it has been aimed to adaptation the scale of teachers' achievement goals to the Turkish culture and get point of their view about their achievement goals within the qualitative questions prepared by base on scale items. As a result of the research, it is concluded that the scale is valid and reliable. Scales' coefficient varies from .11 to .57 . Cronbach's alfa coefficient has been found as .73 for the whole scale. The fit index obtained as a result of confirmatory factor analysis of the scale $\left(\mathrm{x}^{2}=146.78, \mathrm{sd}=51\right.$, $\mathrm{p}=0.0000$, RMSEA $=.08$, NFI $=.89$ NNFI $=.90$, CFI $=.92$, $\mathrm{IFI}=.92, \mathrm{RFI}=.86$, and $\mathrm{SRMR}=.06$ ) shows that three dimensional model fits. Results obtained from the interviews made with teachers to determine their views about tendency to success are as below. Most of the teachers sometimes feel inadequate about their job. It is emphasized that the teachers who feel inadequate are willing to compensate this inadequacy. Most of the teachers have stated that they make researches about their branch to defeat the situations where they feel inadequate. Another notion effecting teachers' tendency to success is self-efficacy [41]. The concept of self-efficacy for teachers is based on a judgement of whether teachers are adequately doing what they need to accomplish their duties [17]. In the teaching profession, the teacher thinks that he or she is sufficient, or that his or her efforts to be sufficient can be considered as steps towards success. It was concluded that teachers perceived themselves as moderate enough, fairly adequate and high enough in the studies aimed at determining self-efficacy perceptions of teachers. Also teachers' level of well-being and job satisfaction effect success tendencies [31, 35]. High motivation and low job burnout are a situation effecting teachers' tendency to success [12]. In this context, self-efficacy, well-being, job satisfaction, motivation and exhaustion perceptions can affect teachers' orientation towards success. It is important for teachers to get to know themselves professionally. A successful teacher always aims at excellence for himself, his school and his students and tries to achieve this goal.

In this research it has been determined that student behaviors, school culture, professional features and environmental and personal factors encourage them to success. The views as willing students as part of student behaviors, positive attitudes of colleagues as part of school culture, desire to be a good teacher as part of personal factors and having successful/ambitious colleagues near them as part of environmental factors stand out. When the researches about the situations effecting teachers' tendency to success have been examined, a close link between students and the teachers have a positive effect on both teachers' and students' tendency to success [9]. In the research about what effects students' tendency to success and motivation, the answers such as planning teaching beforehand [20], school environment and colleagues [26], salary [34], person's own social value and personal factors [33] come to exist. However, the characteristics of effective teachers are expressed in two categories: individual beliefs, attitudes-behaviors and educational skills and approaches [36]. In this context, teachers who focus on the student and exhibit behaviors that support the development of the student in all aspects, who are equipped in all aspects of the professional field, and who develop themselves continuously with the sharing of their colleagues are effective teachers. The effective and successful success of a school is not dependent solely on the success of the teachers who work at that school. At the same time, school culture needs to be developed positively by school administrators. In order for teachers to succeed, the psychological atmosphere offered by the school to teachers is important.The school should create an environment in which the teacher feels safe [1]. In this research it has been stated that most of the teachers follow the latest developments about their branches and nearly half of them attend educational seminars and conferences to be more successful for their jobs. In a study, teacher candidates defined a successful teacher as a teacher who is open to innovation, investigates developments, uses modern technological opportunities, establishes good communication and social relations with his students, 
guides his students to the aims of the course and education in general [15].

In this research it is stated that teachers evaluate themselves in terms of features making more successful teachers than their colleagues, appreciating students, their own characteristic features, the things they do during the education and professional value. The views as caring students as part of appreciating students, being open to the new ideas and being patient determined as part of characteristic features, using student-centered methods in the lessons as part of the things done during the education and working in a willing way as part of professional value have been emphasized. As a result of a research, teachers have determined that the secret of success is to love the profession with their own personal characteristics [43]. In addition, the opinions of successful teachers that they love their students, use the methods and techniques well, participate in professional studies and follow up the current research have come to the fore. In a study with successful and unsuccessful teachers, however, it was determined that successful teachers valued their students and they were happy to be with them, and that unsuccessful teachers treated their students with distance and criticised their students [38]. As a result of the research [40], it was determined that the behaviors of being a model for students in terms of personality characteristics, being prepared and planned in terms of professional competence, managing the class well, preparing suitable learning environments for the individual differences of the students, knowing, loving and making them feel loved by the students, having adequate knowledge, transferring information and following. In study, Kyriakides, Campbell and Christofidou stated that effective teachers should set goals for success, prioritize student needs, value students, love them, work for professional development, share and make feedback with colleagues, develop positive personality structure, and follow change with love for their job [25].

According to the results of the research, the scale adapted in the research can be used to determine the achievement goals orientation of teachers. In this context, different variables (branch, school type, gender, age, vocational seniority) can be determined the effects of teachers on the direction of achievement goals. Seminars and supportive activities can be carried out by school management on issues where teachers feel inadequate. The working environment of teachers, students, administrators and other school staff at school is thought to affect the performance of teachers. In this context, studies can be carried out to determine the level of satisfaction of teachers in order to be moderate in the school environment. Teachers are positively affected by successful colleagues. For this purpose, panels with good examples of teaching profession can be arranged in schools. In this way, teachers have the opportunity to benefit from the experience of experienced and successful teachers in achieving success. Teachers can be provided to follow up with current developments in their fields in order to achieve their achievement goals. In addition, support for teachers to participate in seminars and conferences can be increased. The teaching profession is closely related to the effective implementation of teacher education programs. In this context, the effectiveness of teacher training programs can be increased in order to gain the necessary knowledge, skills, abilities, interests, attitudes, habits and behaviors of teacher candidates by performing product and process evaluation studies. In-service trainings can be planned and implemented effectively in order to ensure that teachers are directed to success.

In conclusion teachers' tendency to success effects students' level of well-being and life. Teachers' achievement goals also encourage students' achievement goals [32]. The goal of success, focusing on high success and always in expectation of success is one of the personality traits of a successful teacher $[14,19]$. In this context, all studies on the development of teachers' achievement goals contribute to the quality of education. The success of the teacher leads to the success of the school and the student.

\section{Appendix}

\section{Başarı hedefleri Ölçeği}

Her sorunun karşısında bulunan;(1) Kesinlikle katılmıyorum (2) Katılmiyorum (3) Kararsızım (4) Katıliyorum (5) Kesinlikle Katılıyorum anlamina gelmektedir

\begin{tabular}{|c|c|c|c|c|c|c|}
\hline 1 & $\begin{array}{c}\text { Başkalarına göre daha iyi öğretmen } \\
\text { olduğumu görünce kesinlikle memnun } \\
\text { olurum }\end{array}$ & 1 & 2 & 3 & 4 & 5 \\
\hline 2 & $\begin{array}{l}\text { Kabiliyetim dışındaki metodların beni } \\
\text { gülünç duruma düşermesinden kaçınırım. }\end{array}$ & 1 & 2 & 3 & 4 & 5 \\
\hline 3 & $\begin{array}{l}\text { Hedefim, öğretmen olarak yeteneklerimi } \\
\text { sürekli geliştirmektir }\end{array}$ & 1 & 2 & 3 & 4 & 5 \\
\hline 4 & $\begin{array}{c}\text { Öğrettiklerim hakkında yeni şeyler } \\
\text { öğrenmek için daha da fazla çalışmak } \\
\text { niyetindeyim }\end{array}$ & 1 & 2 & 3 & 4 & 5 \\
\hline 5 & $\begin{array}{c}\text { Yetersiz görünebileceğim egzersizlerden } \\
\text { kaçınmaya devam edeceğim }\end{array}$ & 1 & 2 & 3 & 4 & 5 \\
\hline 6 & $\begin{array}{l}\text { Öğrettiğim konu hakkında her zaman yeni } \\
\text { şeyler öğrenmek benim için önemlidir }\end{array}$ & 1 & 2 & 3 & 4 & 5 \\
\hline 7 & $\begin{array}{l}\text { Benim tutumum diğerlerinden daha iyi } \\
\text { öğretmen olmaktır }\end{array}$ & 1 & 2 & 3 & 4 & 5 \\
\hline 8 & $\begin{array}{l}\text { Her zaman meslektaşlarımdan daha iyi } \\
\text { olmak için çalışacağım }\end{array}$ & 1 & 2 & 3 & 4 & 5 \\
\hline 9 & $\begin{array}{c}\text { Her ne kadar zor olursa olsun, öğrettiğim } \\
\text { konuyla ilgili olarak yeni şeyler } \\
\text { öğrenmeyi seviyorum }\end{array}$ & 1 & 2 & 3 & 4 & 5 \\
\hline 10 & $\begin{array}{l}\text { Öğretmen olarak, diğerlerinden daha iyi } \\
\text { bir performans göstermek hayatım için } \\
\text { önemlidir }\end{array}$ & 1 & 2 & 3 & 4 & 5 \\
\hline 11 & $\begin{array}{l}\text { Yetersiz görünebileceğim şeyleri } \\
\text { öğretmekten kaçınmak isterim }\end{array}$ & 1 & 2 & 3 & 4 & 5 \\
\hline 12 & $\begin{array}{l}\text { Yetersiz görünebileceğim bir şeyi } \\
\text { öğretmekten kaçındığım zaman } \\
\text { rahatlamış hissederim }\end{array}$ & 1 & 2 & 3 & 4 & 5 \\
\hline
\end{tabular}




\section{REFERENCES}

[1] Ada, Ş. \& Akan, D. (2007). Efficient schools in the change progress. Atatürk Üniversitesi Kazım Karabekir Eğitim Fakültesi Dergisi, 16: 343-373.

[2] Akın,A.(2006). 2X2 Başarı yönelimlerı ölçeği: Geçerlik Ve Güvenirlik Çalışması. SUEFD, 12,1-13

[3] Akın, A., Gündüz, H. B., \& Çetin, B. (2008). Öz-duyarlık ile tükenmişlik: Yapusal eşitlik modeliyle bir inceleme. 15. Ulusal Psikoloji Kongresi, 3-5 Eylül, İstanbul.

[4] Akkoyunlu, B., Orhan, F. \& Umay, A. (2005). Bilgisayar öğretmenleri için "bilgisayar öğretmenliği öz-yeterlik ölçeği" geliştirme çalışması. Hacettepe Üniversitesi Ĕ̆itim Fakültesi Dergisi. 29: 1-8.

[5] Alparslan, M.A., Taş, A.M. \& Yastıoğlu, S. (2017). Bireysel ve sosyal başarı motivasyonunu açıklayan temel değerler: bir alan araștırması. Abant İzzet Baysal Üniversitesi Sosyal Bilimler Enstitüsü Dergisi. 17 (2): 133-151

[6] Alpaslan, G., Bozgeyikli H. \& Avc1, A. (2017). Sinıf öğretmeni adaylarının başarı yönelimleri ile mesleki kaygı düzeylerinin incelenmesi. Abant İzzet Baysal Üniversitesi Eğitim Fakültesi Dergisi. 17 (1): 189-211

[7] Ames, C. \& Archer, J. (1988). Achievement goals in the classroom: Students' learning strategies and motivational processes. Journal of Applied Psychology, 76: 478-487.

[8] Arslan, A. \& Koç, C. (2017). Ortaokul öğrencilerinin akademik öz yeterlik algıları ve okuma stratejileri bilişüstü farkındalıkları. Yüzüncü Yll Üniversitesi Eğitim Fakültesi Dergisi. 14(1): 745-778

[9] Awan, Riffat-Un-Nisa, Ghazala Noureen \& Anjum N. (2011). A study of relationship between achievement motivation, self-concept and achievement in English and mathematics at secondary level. International Education Studies 4(3): 72-79.

[10] Aydın, S., Yalmancı G.S. \& Yel, M. (2014). Fen bilgisi öğretmen adaylarının başarı amaç yönelimlerinin çeşitli değişkenler açısından incelenmesi. Kafkas Üniversitesi, $e-$ Kafkas Eğitim Araştırmaları Dergisi. 1 (1).

[11] Awan,R., Noureen I. \& Naz. A. (2011). A study of relationship between achievement motivation, self-concept and achievement in English and Mathematics at secondary level. International Education Studies, 4(3): 72-79.

[12] Butler, R. (2007). Teachers' achievement goal orientations and associations with teachers' help seeking: Examination of a novel approach to teacher motivation. Journal of Educational Psychology, 99, 241-252.

[13] Cömert, M., Demirtaş, H., Özer N. (2011). Öğretmen adaylarının öz yeterlik inançları ve öğretmenlik mesleğine ilişkin tutumları. İnönü Üniversitesi Eğitim ve Bilim. 36 (159).

[14] Cruickshank, D. R., Jenkins, D. B. \& Metcalf, K. K. (2003). The act of teaching. New York: McGrow Hill.

[15] Deniz, L. (1998). Çağdaş öğretmen, başarılı öğretmen, iyi öğretmen: Öğretmen adaylarının görüşlerine dayanılarak yapılan bir ön değerlendirme. $M \ddot{U}$. Atatürk Eğitim Fakültesi Eğitim Bilimleri Dergisi, 10: 83-95.
[16] Dweck, C.S. \& Leggett, E.L. (1988). A social-cognitive approach to motivation and personality. Psychological Review. 95(2): 256-273.

[17] Goddard, R. D., Hoy, W. K. \& Woolfolk-Hoy, A. W. (2004) Collective efficacy beliefs: Theoretical developments, empirical evidence, and future directions. Educational Researcher, 33(3), 3-13

[18] Gürcan, A. (2005). Bilgisayar özyeterliği algısı ile bilişsel öğrenme stratejileri arasındaki ilişki. Ĕgitim Araştırmaları, 19: 179-193.

[19] Hotaman, D. (2011). Eğitim fakülteleri kendi öğrencilerini seçebilir mi? Kuramsal Ĕ̈itim Bilim Dergisi, 4 (1): 126-136.

[20] Kaiser, J. S. (1981). Motivation deprivation: No reason to stay. The Clearing House: A Journal of Educational Strategies, Issues and Ideas, 55, 35-38.

[21] Karabacak, M. S. (2014). The opinions of high school teachers in Ankara province in relation to teacher autonomy and teacher self-efficacy. Master thesis, Ankara University, Ankara, Turkey.

[22] Karabağ, S. \& Koç, C. (2013). İlköğretim ikinci kademe (6-8. sınıf) öğrencilerinin bilişüstü yetileri ile başarı yönelimlerinin incelenmesi (Bingöl ili örneği). E-Journal of New World Sciences Academy. 8 (2).

[23] Kaya, N. \& Selçuk, S. (2007). Bireysel başarı güdüsü organizasyonel bağl1lı̆̆1 nasıl etkiler?. Doğuş Üniversitesi Dergisi. 8 (2): 175-190

[24] Kurt, T. (2010). Okul yönetiminde insan ilișkileri. Ankara: Nobel.

[25] Kyriakides, L., Campbell, R. J., \& Christofidou, E. (2002). Generating criteria for measuring teacher effectiveness through a self-evaluation approach: A complementary way of measuring teacher effectiveness. School Effectiveness and School Improvement, 13: 291-325. doi:10.1076/sesi.13.3.291.3426

[26] Mani, B. G. (2002). Performance appraisal systems, productivity, and motivation: A case study. Public Personnel Management, 31: 141-159.

[27] McClelland, D. C. (1961). The achieving society. Princeton, NJ: Von Nostrand.

[28] Oral, T. \& Özgüngör, S. (2015). Ergenlerde kimlik statülerinin başarı amaç yönelimlerini yordama gücü. Elementary Education Online, 14(1): 1 - 12.

[29] Özdemir, S. (2016). Öğretmen adaylarının psikolojik ihtiyaçlarının ve kişilik özelliklerinin başarı yönelimlerini yordamadaki rolü. Mehmet Akif Ersoy Üniversitesi Ĕ̆itim Fakültesi Dergisi. (40): 1-19

[30] Özgüngör, S. (2014). Üniversite öğrencilerinde benlik saygısı düzeyine göre kimlik statüleri ile başarı yönelimleri arasındaki ilişki. Pamukkale Üniversitesi Eğitim Fakültesi Dergisi. 35(I): 33-46

[31] Papaioannou, A. \& Christodoulidis, T. (2007). A measure of teachers' achievement goals. Educational Psychology, 3, 349-361.

[32] Paulick, I., Retelsdorf, J., \& Möller, J. (2013). Motivation for choosing teacher education: Associations with teachers' 
achievement goals and instructional practices. International Journal of Educational Research, 61, 60-70.

[33] Peterson, M. F., \& Ruiz-Quintanilla, S. A. (2003). Cultural socialization as a source of intrinsic work motivation. Group \& Organization Management, 28, 188-216.

[34] Praver, M., \& Oga-Baldwin, W. (2008). What motivates language teachers: Investigating work satisfaction and second language pedagogy? Polyglossia, 14, 1-8.

[35] Retelsdorf, J., Butler, R., Streblow, L., \& Schiefele, U. (2010). Teachers' goal orientations for teaching: Associations with instructional practices, interest in teaching, and burnout. Review of Educational Research, 20, 30-46.

[36] Sakız, G. (2016). Effective teaching and improving teacher quality. Journal of Theoretical Science, 9 (2): 214-244.

[37] Saracaloğlu, A. S., Karasakaloğlu, N. \& Evin-Gencel, İ. (2010). Analysis on Turkish teachers' self-efficacy levels according to various variables. Electronic Journal of Social Sciences, 9 (33): 265-283.

[38] Smith, J. M. \& Lusterman D. D. (1979). The teacher as learning facilitator: Psychology and the educational process. Belmont: Wardsworth Publishing Company.

[39] Şahin, E. (2010). Effects of elementary school classroom teachers' teaching style preferences, genders, lengths of professional service, self-efficacy perceptions and selfdirected learning readiness levels on their professional competency. Doctoral Thesis, Y1ldız Technical University, İstanbul, Turkey.

[40] Sahin, A. (2011). Effective teacher's Attitudes According to teacher's perceptions. Ahi Evran Üniversitesi Ë̆itim Fakültesi Dergisi,12 (1): 239-259.

[41] Turner, A. (2014). Elementary teachers' achievement goal orientations in a high-stakes accountability context: A validation study. Virginia Commonwealth University.

[42] Üstüner, M., Demirtaş, H., Cömert, M. \& Özer, N. (2009). Secondary school teachers' self-efficacy beliefs. Mehmet Akif Ersoy Üniversitesi Ĕ̈itim Fakültesi Dergisi, 9 (17): 1-16.

[43] Yıldırım, N. \& Öner, S. (2016). A qualitative analysis on efficient / successful class teachers. Ahi Evran Üniversitesi Kırşehir Eğitim Fakültesi Dergisi (KEFAD), 17 (3): 135-155.

[44] Y1ldırım, A. \& Şimşek, H. (2013). Sosyal bilimlerde nitel araştırma yöntemleri. Ankara: Seçkin Yayıncılık.

[45] Zayimoğlu-Öztürk, F. (2011). Investigation of social studies teachers' and social studies teacher candidates' self efficacy in the learning strands of the primary school social studies curriculum. Doctoral thesis, Gazi University, Ankara, Turkey. 